\title{
Factors affecting the quality of social infrastructure projects in industrial Hanoi, Vietnam
}

\author{
Thi Thanh Tam Nguyen ${ }^{a}$, Hoa Phuong Tran ${ }^{b}$ and Thuy Ha Dao ${ }^{c^{*}}$
}

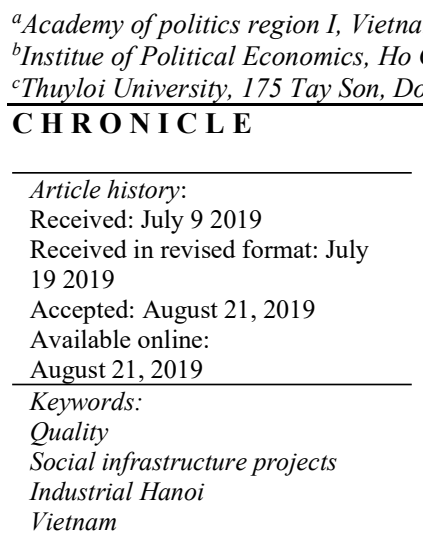

\section{Introduction}

The industrialization and modernization of the country, especially after "Doi moi" has brought numerous positive changes on the socio-economic development and improvement of Vietnamese people's material life (Ali et al., 2010). The introduction and development of major economic region, especially with the strong development of industrial zones (IZ), export processing zones in Vietnam are both opportunity and great challenge for the State and other socio-economic objects. With over 300 concentrated industrial zones in the whole country (Vietnam Industrial Zone-2018), there is an enormous motivation for shifting economic structure, labor structure in line with the trend of international economic integrity, promoting the process of acquiring modern technology, creating a large number of jobs and increasing workers' income. However, industrial zones are facing numerous great challenges such as weakness of general planning leading to the "temporary" development of industrial zones and many industrial zones encounter difficulties in attracting investment from businesses. In addition, the management mechanism and administrative activities for industrial zones are ineffective; the human resources for industrial zones have not met the demand, especially workers with high-quality skills; the environmental pollution in many industrial zones are annoying. In particular, one current pressing problem is to build and develop social infrastructure for workers in concentrated industrial zones that is in need of adequate attention from all levels, sectors, particularly from policy makers and enforcement.

Currently, in Hanoi, there are 19 concentrated industrial zones creating regular jobs for nearly 300 thousand workers (Hanoi Industrial and Export Processing Zones Authority - 2018). Almost every industrial zone mainly focuses on building and developing infrastructure for production and economic interests needs to pay adequate attention for the development of social infrastructure for workers. In particular, it can be said that workers' material and spiritual life is one of the factors determining the quality of labor resources and affecting the economic efficiency in general. Spontaneous residential areas are posing threats of numerous social evils as well as unpredictable consequences. Social infrastructure systems do not only bring about a decent

* Corresponding author. Tel. : +84 0904106676

E-mail address: ntdaoha@gmail.com (T. H. Dao) 
appearance beside industrial zones but also create great challenges for social community in general and economic management system in particular (Barney, 1986; Hall, 1993). Therefore, to synchronize the development of industrial zones with the construction of social infrastructure (Housing, health, education, recreation, urban environment) there is a need to pay attention oo the whole society. Social infrastructure projects in industrial zones are still fragmented, ineffective, which affects the workers' material and spiritual life. Therefore, in order to improve the quality of social infrastructure projects in industrial zones, we must, in the first place, be aware of which factors affecting the quality of social infrastructure projects.

The objective of this research is to assess factors affecting the quality of social infrastructure projects in industrial zones in Hanoi, Vietnam.

\section{Research overview}

\subsection{Social infrastructure projects}

Social infrastructure in industrial zones means a system of works serving the demands and services of people, administrative apparatus and manufacturing facilities. This system of works includes: Administration, health, education, culture, fitness sports, commercial services, park trees and other works (except for urban technical infrastructure works), which are organized and interconnected in the space of industrial zones. The concept of social infrastructure projects emerged in the last decade mainly because of the fact that the society in general has a great interest in public infrastructure. Argy et al. (1999) and Jefferies and McGeorge (2009) categorized the social infrastructure into hard social infrastructure (e.g. hospital, school, and community hall) and soft social infrastructure (e.g. social security and education). Therefore, social infrastructure can refer to the construction and public facilities or services like training, education and security. However, this article only focuses on hard social infrastructure (buildings or facilities serving society's need). Social Infrastructure Projects (SIPs) relate to many partners including, in most cases, different government agencies, private companies and non-profit organizations. Even though SIPs often are smaller in size than economic infrastructure, they are as complex and dynamic as common construction projects because the post-construction phase and maintenance relating to the public involvement (Jefferies \& McGeorge, 2009).

Previous studies focused primarily on SIPs testing in the Public Private Partnership (PPP) method (Jefferies \& McGeorge, 2009; Donno et al. 2010; Baron \& Kenny, 1986; Le et al., 2019). The studies also focused on specific SIPs, such as stadium (Jefferies et al., 2002), house renovation (Donno et al. 2010), hospital (Love et al., 2002) and school (Love et al., 2012). Jefferies et al. (2002) identified six factors to be successful in stadium project including expertise, experience, construction company profile, reputation, approval process to support Stakeholder and financial method innovation. These studies were limited because they focused on the context of the PPP method and on case study methods, leaving a gap in the field of SIPs.

Therefore, the previous studies on SIPs show that it is necessary to explore the factors affecting the quality of social infrastructure projects in a more specific way, to provide a general framework for the factors affecting the quality of SIPs.

\subsection{Factors affecting the quality of social infrastructure projects in industrial zones}

The social infrastructure of the industrial zones is the system of houses, schools, hospitals, cultural institutions to directly serve workers in the industrial zones. The social infrastructure of the industrial zones can be constructed in the specific planning of industrial zones or outside the fence of industrial zones (Heavey \& Simsek, 2013; Ireland et al., 2003; Hult et al., 2003). Most industrial zones in Vietnam have a small area so there is no planning for the construction of social infrastructure inside the fence of industrial zones. The scope of the research will be focused on analyzing factors affecting the quality of social infrastructure projects to serve industrial zones, including: Housing system, schools, medical facilities and cultural institutions to meet the daily living needs of workers working in the industrial zones in Hanoi and their families. By using the PLS - SEM technique, a model has been developed and a total of 31 items affecting the quality of social infrastructure project are named as observance variables and categorized into groups. The groups are exogenous latent structures such as factors relating to Construction Related, Design Related, External Related, Material Related, Stakeholder Related. Whereas, the endogenous latent variable (Quality of Social Infrastructure Projects) includes observed variable. The conceptual model presents the relationship between exogenous latent structure and endogenous latent structure as shown in Fig. 1. Therefore, the quality of the project is calculated by main structures. The research hypotheses are as follows:

\section{Research Methods}

\subsection{Context and research sample}

According to Hanoi Industrial and Export Processing Zones Authority (HIZA), the city has been going to develop 19 industrial zones (IZ), high technology zones (HTZ) with a total area of nearly 4,100 ha. In which, the city is carrying out the construction of 3 HTZ together with 110 industrial clusters with planning area of more than 3,000 ha. Up to the end of August 2016, the active industrial zones have attracted 616 projects (323 foreign direct investment projects - FDI) with registered capital of USD 5.22 billion, the disbursed capital is USD 3.28 billion, most of the investors come from Japan, Korea, China and Singapore including 293 domestic projects with registered capital of VND 11.981 billion (the disbursed capital is VND 7.168 billion). Among the FDI projects, many of which belong to world's leading corporations, hi-tech products such as Canon, Panasonic, Hoya, Meiko (Japan), etc. (Kura, 2016; Kura et al., 2016) 
The data collection was carried out by an agency that often surveys public construction projects. This sample is selected from a list of public construction industries in Hanoi, Vietnam. Participants are public construction experts. A total of 690 participants were randomly selected to answer the questionnaire. The survey agency sent email and interviewed in-person to collect data for the research. The questionnaire is divided into two main parts. Part 1 includes participants' general information such as years of experience, professional qualifications, position and type of industry. Part 2 consists of items of latent variables designed in the form of Likert scale from 1 (Strongly disagree) to 5 (Strongly agree). In the period of 3 continuous months, we were able to collect 536 survey forms; however, after data classification and cleaning, only 396 valid survey forms were suitable to be taken into data analysis. In order to increase the credibility of the research, after data analysis, we also conducted many interviews with experts and managers of social infrastructure projects on the survey results.

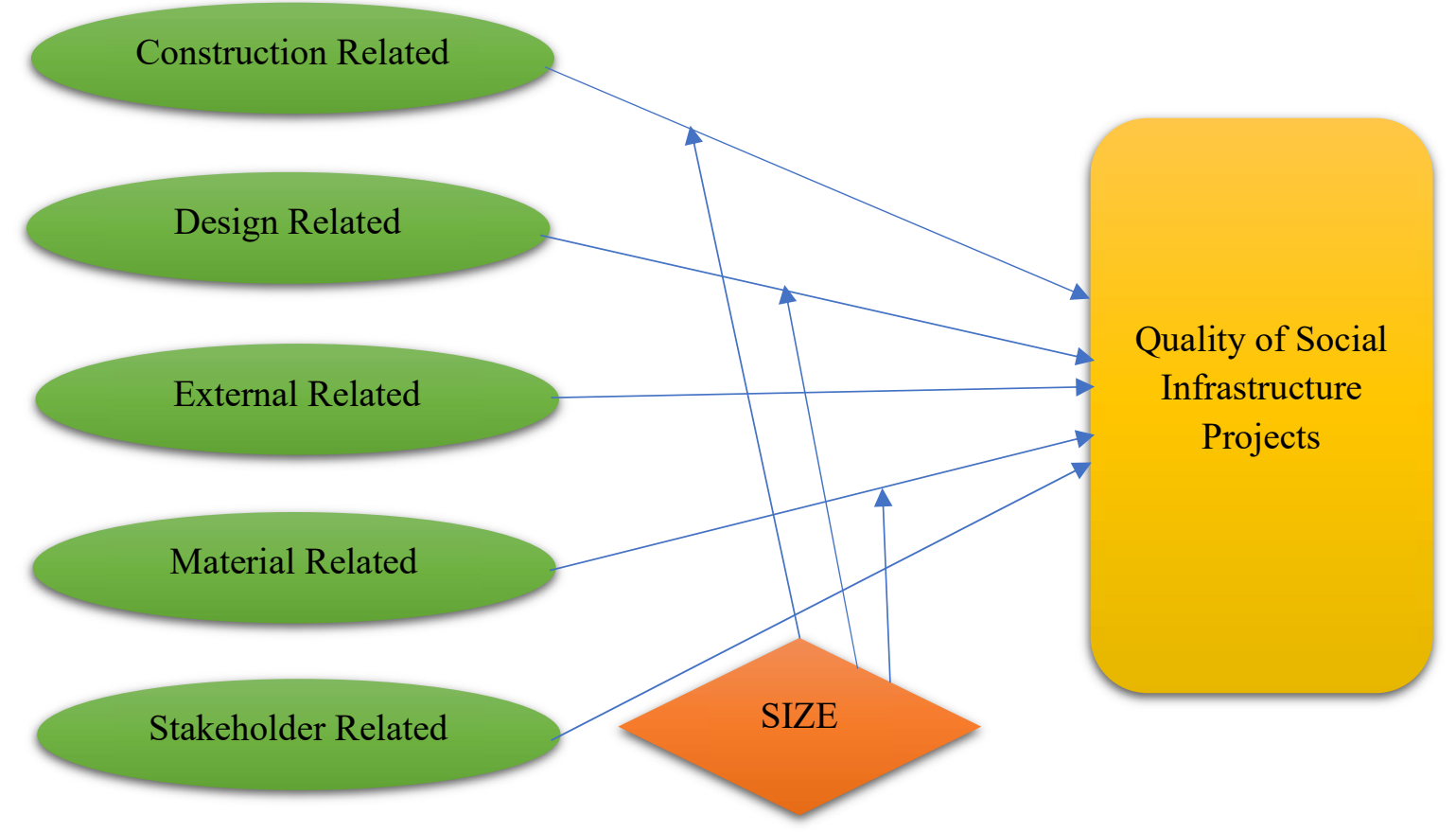

Fig. 1. The proposed method

\section{Research result}

The reliability of indicator variable (also known as observed variable): In reflective model, indicator variables are explained with latent variables, the factor loading of indicator variables is $>=0.7$ (or 0.40 may be acceptable in exploratory testing (Hair et al., 2006, 2010, 2011, 2012a, 2012b). All the measuring scales in the model are satisfying.

Internal Consistency Reliability: The internal Consistency Reliability is measured through Cronbach's alpha value (Henseler et al., 2009; Henseler \& Sarstedt, 2013; Henseler \& Fassott, 2010; Lee et al., 2011) with an acceptable value of 0.7 in the initial research periods and each latent variable must have at least 2 indicator variables. All the latent variables in the model are satisfying.

Result of general reliability testing of latent variables

Table 1

Construct Reliability and Validity

\begin{tabular}{ccccc}
\hline & $\begin{array}{c}\text { Cronbach's } \\
\text { Alpha }\end{array}$ & rho_A & $\begin{array}{c}\text { Composite Reli- } \\
\text { ability }\end{array}$ & $\begin{array}{c}\text { Average Variance Ex- } \\
\text { tracted (AVE) }\end{array}$ \\
\hline Construction Related & 0.945 & 0.948 & 0.944 & 0.773 \\
Design Related & 0.920 & 0.920 & 0.919 & 0.694 \\
External Related & 0.923 & 0.941 & 0.926 & 0.809 \\
Material Related & 0.838 & 0.844 & 0.838 & 0.635 \\
Quality of Social Infrastructure Projects & 0.949 & 0.950 & 0.949 & 0.650 \\
Stakeholder Related & 0.910 & 0.912 & 0.905 & 0.617 \\
\hline
\end{tabular}


Convergent validity: The convergent validity evaluates the correlation of measurement indicators with 1 latent variable. The convergent validity of the scale is measured through:

- For exploratory testing, the composite reliability factor (CR) is in the range of $0.6-0.7$, but the ideal one should be $\geq 0.7$;

- The external factor loading of the observed variables must be $\geq 0.708$;

- The average variance extracted (AVE), reflecting the general variability of observed variables calculated by latent variables, must be $\geq 0.5\left(0.708^{2}=0.5\right)$ (Henseler et al., 2015; José \& Manuel, 2012); and the rho_A coefficient must be $>0.7$.

In conclusion, all the variables in the model shown in the Table 1 satisfy the conditions, and continue to be analyzed for discriminant validity.

The result of discriminant validity analysis is as follows:

Discriminant validity: The discriminant validity determines the discriminant value to guarantee the difference and there is no correlation among the factors used to measure the factors. Distinct value is an important criterion in measurement model analysis. It measures the distinction among concepts in the research model (Henseler et al., 2015). There are 2 levels when it comes to reviewing discriminant validity, which are:

- The extent of distinction among the components in the same concept (within construct, if the concept is level 2 or above);

- The extent of across construct distinction among different concepts, or it refers to saturated model (the concepts in research model are freely related to each other).

The discriminant validity is considered to be valid if the value of the HTMT (heterotrait - monotrait) criterion is $<0.85$ (Henseler et al., 2015; Chin, 1998, 2010; Chin et al., 2003) or the square root of AVE of each measuring factor is greater than correlation coefficient among the factors. It can be seen from Table 2 that all the square roots of AVE are greater than the correlation coefficient among the factors, thus, satisfy the analysis conditions.

Table 2

Discriminant Validity (Fornell-Larcker Criterion)

\begin{tabular}{|c|c|c|c|c|c|c|}
\hline & $\begin{array}{l}\text { Construction } \\
\text { Related }\end{array}$ & $\begin{array}{l}\text { Design } \\
\text { Related }\end{array}$ & $\begin{array}{l}\text { External } \\
\text { Related }\end{array}$ & $\begin{array}{l}\text { Material } \\
\text { Related }\end{array}$ & $\begin{array}{c}\text { Quality of Social } \\
\text { Infrastructure Projects }\end{array}$ & $\begin{array}{c}\text { Stakeholder } \\
\text { Related }\end{array}$ \\
\hline Construction Related & 0.879 & & & & & \\
\hline Design Related & 0.236 & 0.833 & & & & \\
\hline External Related & 0.284 & 0.486 & 0.899 & & & \\
\hline Material Related & 0.360 & 0.219 & 0.249 & 0.797 & & \\
\hline Quality of Social Infrastructure Projects & 0.340 & 0.515 & 0.358 & 0.282 & 0.806 & \\
\hline Stakeholder Related & 0.176 & 0.477 & 0.469 & 0.202 & 0.402 & 0.785 \\
\hline
\end{tabular}

Table 3

Inner VIF Values

\begin{tabular}{|c|c|c|c|c|c|c|}
\hline & $\begin{array}{c}\text { Construction } \\
\text { Related }\end{array}$ & $\begin{array}{c}\text { Design Re- } \\
\text { lated }\end{array}$ & $\begin{array}{c}\text { External Re- } \\
\text { lated }\end{array}$ & $\begin{array}{l}\text { Material Re- } \\
\text { lated }\end{array}$ & $\begin{array}{l}\text { Quality of Social Infrastruc- } \\
\text { ture Projects }\end{array}$ & $\begin{array}{c}\text { Stakeholder } \\
\text { Related }\end{array}$ \\
\hline Construction Related & & & & & 1.214 & \\
\hline Design Related & & & & & 1.483 & \\
\hline External Related & & & & & 1.511 & \\
\hline Material Related & & & & & 1.194 & \\
\hline $\begin{array}{l}\text { Quality of Social Infrastruc- } \\
\text { ture Projects }\end{array}$ & & & & & & \\
\hline Stakeholder Related & & & & & 1.438 & \\
\hline
\end{tabular}

The result of internal multicollinearity is satisfied

Table 4

The results of Fit Summary

\begin{tabular}{lcc}
\hline & Saturated Model & Estimated Model \\
\hline SRMR & 0.052 & 0.044 \\
d ULS & 1.156 & 1.153 \\
d_G & 0.889 & 0.886 \\
Chi-Square & $1,725.148$ & $1,723.231$ \\
NFI & 0.853 & 0.838 \\
\hline
\end{tabular}

From Table 4 it can be seen that research data is fit for research model 
Research hypotheses test result

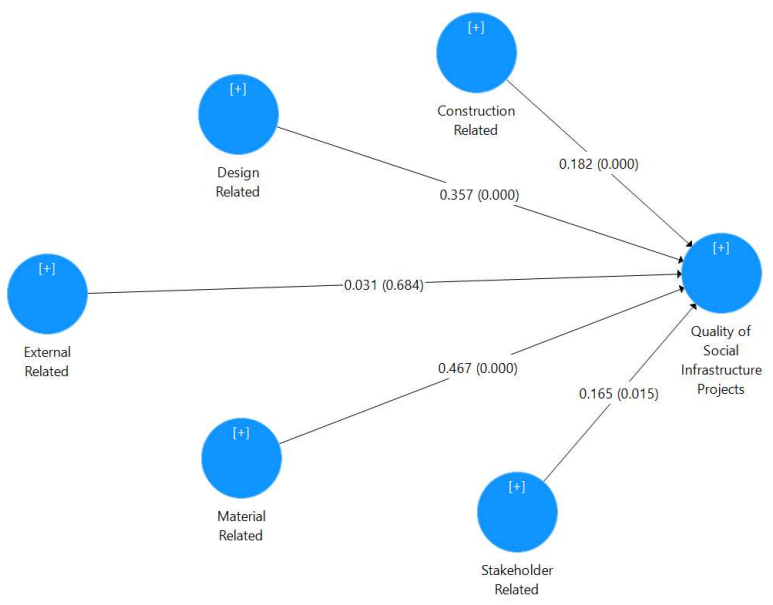

Fig. 2. Bootstrap results

Summary of research hypotheses testing result

Table 5

Mean, STDEV, T-Values, P-Values

\begin{tabular}{|c|c|c|c|c|c|}
\hline & $\begin{array}{c}\text { Original Sample } \\
(\mathrm{O})\end{array}$ & $\begin{array}{c}\text { Sample } \\
\text { Mean (M) }\end{array}$ & $\begin{array}{c}\text { Standard Deviation } \\
\text { (STDEV) }\end{array}$ & $\begin{array}{c}\text { T Statistics } \\
(|\mathrm{O} / \mathrm{STDEV}|)\end{array}$ & $\begin{array}{c}\mathrm{P} \\
\text { Values }\end{array}$ \\
\hline Construction Related $\rightarrow$ Quality of Social Infrastructure Projects & 0.182 & 0.178 & 0.052 & 3.509 & 0.000 \\
\hline Design Related $\rightarrow$ Quality of Social Infrastructure Projects & 0.357 & 0.360 & 0.064 & 5.566 & 0.000 \\
\hline External Related $\rightarrow$ Quality of Social Infrastructure Projects & 0.031 & 0.028 & 0.077 & 0.408 & 0.684 \\
\hline Material Related $\rightarrow$ Quality of Social Infrastructure Projects & 0.097 & 0.102 & 0.051 & 6.882 & 0.000 \\
\hline Stakeholder Related $\rightarrow$ Quality of Social Infrastructure Projects & 0.165 & 0.169 & 0.067 & 2.450 & 0.015 \\
\hline
\end{tabular}

The results summary in Fig. 2 and Table 5 show that hypothesis $\mathrm{H}_{1}, \mathrm{H}_{2}, \mathrm{H}_{3}, \mathrm{H}_{4}$ are supported with the exception of the rejection of hypothesis $\mathrm{H}_{5}$. That means, Material Related has the greatest positive impact on the Quality of Social Infrastructure Projects with an impact factor of 0.467 at the $1 \%$ level of significance $(\mathrm{P}$-value $=0.000)$, the second greatest impact on Quality of Social Infrastructure Projects is Design related with a relatively high impact factor of 0.357 at the $1 \%$ level of significance $(\mathrm{P}$-value $=0.000)$. Construction Related has a positive impact on Quality of Social Infrastructure Projects with an impact factor of 0.182 at the $1 \%$ level of significance $(\mathrm{P}$-value $=0.0000)$. Stakeholder Related has a positive impact on Quality of Social Infrastructure Projects with an impact factor of 0.165 at the $5 \%$ level of significance (P-value $=0.0000)$. External Related has no statistically significant correlation with Quality of Social Infrastructure Projects.

Moderate role test result

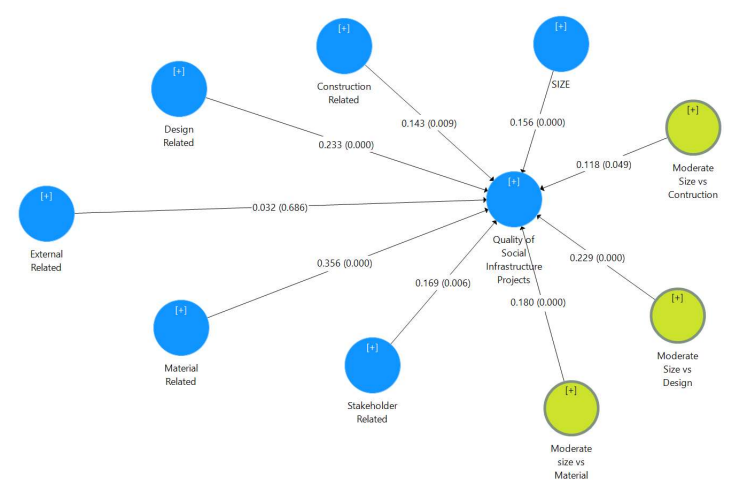

Fig. 3: Moderate role results

The bootstrapping results in Fig. 3 indicate that the project size plays a moderate role with statistical significance in 3 correlations between Material Related and Quality of Social Infrastructure Projects with an impact factor of 0.180 at the $1 \%$ level 
of significance $(\mathrm{P}-\mathrm{value}=0.000)$, the impact factor of the correlation between Design related and Quality of Social Infrastructure Projects is 0.229 at the $1 \%$ level of significance $(\mathrm{P}$-value $=0.000)$, and lastly, there is a positive relationship between Construction Related and Quality of Social Infrastructure Projects with an impact factor of 0.118 at the $1 \%$ level of significance $(\mathrm{P}-\mathrm{value}=0.000)$.

With the above-mentioned impact factors, the model is as follows:

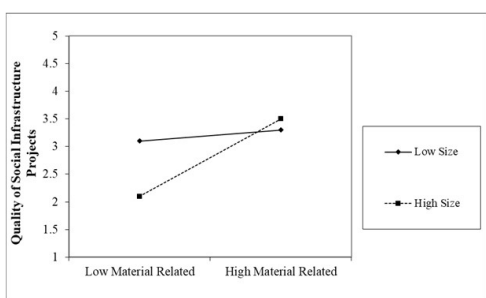

Fig. 4: Moderate role of size

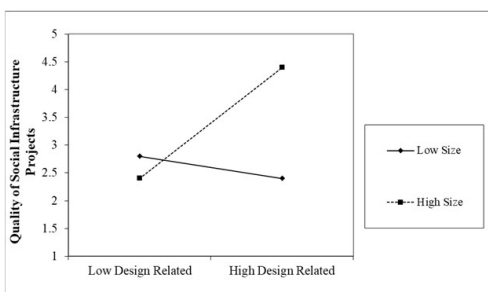

Fig. 5: Moderate role of Size with Design related

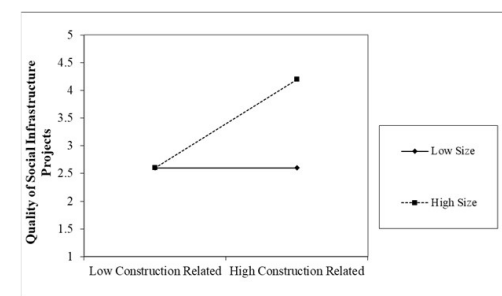

Fig. 6. Moderate role of Size with Construction related

The result in Fig. 4 means that the bigger the size of Social Infrastructure Projects is, the better the quality of materials is, which results in the significant improvement of the project quality. However, the poor quality of materials does not only lessen the project quality considerably but also it has positive impact on the project quality. It is because of the fact that the input materials for these projects are strictly controlled; therefore, if the quality of materials is not good enough, it can still meet the minimum requirements of quality of social infrastructure projects. In contrast to input materials, the project size causes design to make an opposite impact on the quality of the project. For larger social infrastructure project, the better the design is, the better quality of the project. However, for small project, the better the design is, the worse the quality of the project is. It is because, for small project, sophisticated designs will cost a large amount of money and will reduce expenses for other sectors. One feature of these projects is that they have a fixed budget; therefore, if the design expense accounts for a large proportion, other expenses will be reduced leading to the decrease in the quality of the project.

\section{Moderate role of construction related}

In the last place comes the moderate impact of project size on the context of Construction. For projects with larger size, the better the construction model is, the better the quality of the project is. On the other hand, the role of construction becomes comparatively vague in small projects. (Horizontal impact line).

\section{Conclusion}

Modern and synchronous infrastructure will promote economic growth, improve productivity and economic efficiency and contribute to solving social problems. On the other hand, an underdeveloped infrastructure will become a great burden to the development. Nowadays in many developing countries, insufficient and poor infrastructure has caused stagnation to the flow of resources, difficulties in absorbing investment capital, causing "infrastructure bottleneck" which directly affects the economic development, especially the sustainable development of industrial zones in the whole country in general and industrial zones in Hanoi in particular.

The issues of quality in public construction of Vietnam are sophisticated and full of risk, including many factors throughout the project life cycle, which reduces not only the quality of the project but also the sustainability of the entire project.

Previous documents on the factors affecting the quality of construction project adopted the same method of simple linear model analysis using SPSS. The objective of this research was to present and introduce a new method to analyze and test the impact of the main structures on the quality of SIPs. An advanced multivariate analytic technique, PLS-SEM, was adopted to conduct the analysis. This comprehensive multivariate statistical testing technique can examine all the correlations between latent variables and variables in a model, and also include an evaluation of the structure and measurement models. Another reason for the adoption of this technique was its capability of assessing psychological attributes of separate latent structures. The fundamental structures affecting the quality of the project with their underlying causes (observed variables) have been clearly identified.

This research was conducted to find out factors affecting the quality of SIPs in industrial zones in Hanoi, Vietnam. Based on the results of the survey, it is assumed that material-related factor was the leading factor causing reduction in the quality of the project when carried out in the actual works. This implies that industries and public construction contractors are in need of creating specific plans and methods to focus on the issues of the construction phase that affect the quality of the project. The lack of construction and design technologies will increase the pace in which the quality of the project deteriorates in the construction phase as well as the lack of appropriate quality control and policies and quality planning, causing issues to the quality of the projects. Besides, the quality of the project is also affected by Stakeholder.

Consequently, it is essential for businesses and project managers to have detailed plans to improve the quality of social infrastructure projects in industrial zones of Vietnam in general and of Hanoi in particular. 


\section{References}

Argy, F. (1999). Distributional effects of structural change: some policy implications. Structural Adjustment: Exploring Policy Issues, 39-92.

Ali, I., Rehman, K.U., Ali, S.I., Yousaf, J. \& Zia, M. (2010). Corporate social responsibility influences, employee commitment and organizational performance. African Journal of Business Management, 4(13), 2796-2801.

Barney, J.B. (1986). Organizational culture: can it be a source of sustained competitive advantage? Academy of Management Review, 11(3), 656-665.

Baron, R.M. \& Kenny, D.A. (1986). The moderator-mediator variable distinction in social psychological research: conceptual, strategic, and statistical considerations. Journal of Personality and Social Psychology, 51(6), 1173-1182.

Chin, W.W. (1998). The partial least squares approach to structural equation modeling. Modern Methods for Business Research, 295(2), 295-336.

Chin, W. (2010). How to write up and report PLS analyses, in Vinzi, V.E.

Chin, W.W., Marcolin, B.L. \& Newsted, P.R. (2003). A partial least squares latent variable modeling approach for measuring interaction effects: results from a Monte Carlo simulation study and an electronic-mail emotion/adoption study. Information Systems Research, 14(2), 189-217.

Donno, R., Parker, G., Gilmour, J., \& Skuse, D. H. (2010). Social communication deficits in disruptive primary-school children. The British Journal of Psychiatry, 196(4), 282-289.

Fornell, C. \& Larcker, D.F. (1981). Evaluating structural equation models with unobservable variables and measurement error. Journal of Marketing Research, 18(1), 39-50.

Hall, R. (1993). A framework linking intangible resources and capabilities to sustainable competitive advantage. Strategic Management Journal, 14(8), 607-618.

Hair, J.F., Jr, Black, W., Babin, B., Anderson, R. \& Tatham, R. (2006). Multivariate Data Analysis. 6th ed., Prentice Hall, Upper Saddle River, NJ.

Hair, J.F., Black, W.C., Babin, B.J. \& Anderson, R.E. (2010). Multivariate Data Analysis. 7th ed., Prentice Hall, Upper Saddle River, NJ.

Hair, J.F., Ringle, C.M. \& Sarstedt, M. (2011). PLS-SEM: indeed a silver bullet. Journal of Marketing Theory and Practice, 19(2), 139-152.

Hair, J.F., Sarstedt, M., Pieper, T.M. \& Ringle, C.M. (2012a), The use of partial least squares structural equation modeling in strategic management research: a review of past practices and recommendations for future applications. Long Range Planning, 45 (5/6), 320-340.

Hair, J.F., Sarstedt, M., Ringle, C.M. \& Mena, J.A. (2012b), An assessment of the use of partial least squares structural equation modeling in marketing research, Journal of the Academy of Marketing Science, 40(3), 414-433.

Henseler, J., Ringle, C.M. \& Sinkovics, R.R. (2009). The use of partial least squares path modeling in international marketing. Advances in International Marketing (AIM), 20, 277-320.

Henseler, J. \& Sarstedt, M. (2013), Goodness-of-fit indices for partial least squares path modeling. Computational Statistics, 28(2), 565-580.

Henseler, J. \& Fassott, G. (2010). Testing moderating effects in PLS path models: An illustration of available procedures. Handbook of Partial Least Squares, Springer, Heidelberg, Berlin, 713-735.

Heavey, C. \& Simsek, Z. (2013). Top management compositional effects on corporate entrepreneurship: the moderating role of perceived technological uncertainty. Journal of Product Innovation Management, 30(5), 837-855.

Hult, G.T.M., Snow, C.C. \& Kandemir, D. (2003). The role of entrepreneurship in building cultural competitiveness in different organizational types. Journal of Management, 29(3), 401-426.

Ireland, R.D., Kuratko, D.F. \& Covin, J.G. (2003), Antecedents, elements, and consequences of corporate entrepreneurship strategy. Academy of Management Proceedings, Academy of Management, 2003(1), L1-L6.

Jefferies, M., Gameson, R. O. D., \& Rowlinson, S. (2002). Critical success factors of the BOOT procurement system: reflections from the Stadium Australia case study. Engineering, Construction and Architectural Management, 9(4), 352-361.

Jefferies, M., \& McGeorge, W. D. (2009). Using public-private partnerships (PPPs) to procure social infrastructure in Australia. Engineering, Construction and Architectural Management, 16(5), 415-437.

Le, T., Nguyen, T., Phan, T., Tran, M., Phung, X., Tran, T., \& Giao, K. (2019). Impact of corporate social responsibility on supply chain management and financial performance in Vietnamese garment and textile firms. Uncertain Supply Chain Management, 7(4), 679-690.

José, L.R. \& Manuel, J.S.-F. (2012), Variance-based structural equation modeling: guidelines for using partial least squares in information systems research, in Manuel, M., Ovsei, G., Annette, L.S. and Mahesh, R. (Eds), Research Methodologies, Innovations and Philosophies in Software Systems Engineering and Information Systems, IGI Global, Hershey, PA, pp. 193-221.

Kura, K.M. (2016). Linking environmentally specific transformational leadership and environmental concern to green behaviour at work. Global Business Review, 17(S3), 1S-14S.

Kura, K.M., Shamsudin, F.M., \& Chauhan, A. (2015). Does self-regulatory efficacy matter? Effects of punishment certainty and punishment severity on organizational deviance, SAGE Open, 5(2), 2158244015591822.

Lee, L., Petter, S., Fayard, D. \& Robinson, S. (2011). On the use of partial least squares path modeling in accounting research. International Journal of Accounting Information Systems, 12(4), 305-328. 
Love, A. W., Kissane, D. W., Bloch, S., \& Clarke, D. M. (2002). Diagnostic efficiency of the Hospital Anxiety and Depression Scale in women with early stage breast cancer. Australian \& New Zealand Journal of Psychiatry, 36(2), 246-250.

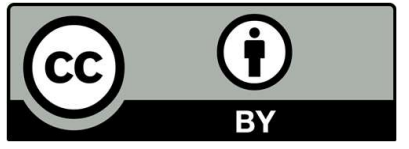

(C) 2020 by the authors; licensee Growing Science, Canada. This is an open access article distributed under the terms and conditions of the Creative Commons Attribution (CCBY) license (http://creativecommons.org/licenses/by/4.0/). 